\title{
Examining the Effect of Altman's Zeta Model Score on the Share Price of Healthcare Companies Listed at Kuwait Stock Exchange
}

\author{
Musaed S. AlAli ${ }^{1}$ \\ ${ }^{1}$ College of Business Studies, Department of Insurance and Banking, The Public Authority for Applied \\ Education and Training (PAAET), Kuwait \\ Correspondence: Musaed S. AlAli, College of Business Studies, Department of Insurance and Banking, The \\ Public Authority for Applied Education and Training (PAAET), Kuwait. E-mail: ms.alali@ paaet.edu.kw
}

Received: January 27, 2019

Accepted: March 5, 2019

Online Published: March 13, 2019

doi:10.5539/ijef.v11n4p25

URL: https://doi.org/10.5539/ijef.v11n4p25

\begin{abstract}
The aim of this study is to examine the financial soundness and the effect of Altman's Zeta model score on the share price of healthcare companies listed at Kuwait stock exchange (KSE) over the period 2013-2017. Zeta model is a widely used model in examining the probability of bankruptcy for companies; it has been proven to be a reliable model in measuring the financial soundness for companies. Results obtained from this study showed that both companies under study, Yiaco and Advanced Technology, are confronting financial difficulties and are facing the risk of bankruptcy. The study also revealed that there is a statistically significant direct relation between Zeta score and the share price of these companies indicating that Kuwaiti investors do take the financial distress indicators into consideration when making their investment decisions.
\end{abstract}

Keywords: Altman bankruptcy model, Zeta model, Healthcare sector, Kuwait stock exchange market (KSE), share price

\section{Introduction}

The healthcare sector in Kuwait stock exchange is made of only two companies, which are Yiaco and Advanced Technology. Advanced Technology was established in July 1981 while Yiaco was established in April 1964. The ownership structure of these two companies in 2017 shows that the largest five stakeholders in Advanced Technology control $87.27 \%$ of the company's outstanding shares while the largest five owners in Yiaco control $76.9 \%$ of its shares. The ownership structure of these companies indicates that a large portion of the healthcare system in Kuwait is controlled by a handful of individuals which gives them a kind of a monopoly over that sector. This monopoly gave them the ability of artificially inflate the prices of the products and the services they provide, making the ministry of public health in Kuwait under the mercy of these companies since under the Kuwaiti law ministries are not allowed to make direct purchase from the mother companies but they should only buy through the agents of these companies in Kuwait. These two companies are the major providers of medical drugs and medical equipments for both the public and private hospitals, clinics and pharmacies in Kuwait. As a result, the financial soundness of these companies is vital for their shareholders, the healthcare sector, and the whole economy.

Altman's (1968) model is a model that is based on financial ratios to determine the probability of bankruptcy and provides an early warning system for companies. As a result of its success in doing so, the model has become the most widely used model in predicting financial failure among researchers and practitioners. Al Gagawi and Ibrahem (2015) believe that quantitative indicators (ratios) are more appropriate than qualitative based models as they are derived from the company's financial reports, which reflect its operating performance. Husein and Pambekti (2014) concluded that the used of financial ratios is an efficient way for diagnosing and analyzing the financial soundness and anticipate future financial difficulties for companies. In addition, Back et al. (1994) found that financial models based on financial ratios outperforms the models that are based on common financial variables. Altman, Haldeman, and Narayanan (1977) developed a new model and claimed that the new model, called Zeta model, would be able to detect bankruptcy with an accuracy rate reaching $90 \%$ two years prior to its occurance. Bredart (2014) used Altman's z-score to examine 870 firms listed in Amex, Nasdaq, and NYSE over the period 1:2000 to 12:2012 and concluded that Altman model had a prediction accuracy of $83.82 \%$. Georheta and Georgia (2012) used Altman's z-score model to identify bankrupt and non-bankrupt companies in the 
Romanian stock market in 2008. They concluded that nearly 52\% (14 of the 27 companies) of the Romanian companies faced financial problems and were threatened with bankruptcy. AlAli (2018) examined the probability of financial distress of mobile telecommunications companies listed at Kuwait stock exchange over the period 2013 to 2016 using Altman's z-model. The study concluded that two out of the three companies under study were facing financial difficulties while the third company had a healthy financial position. Zeta model was able to achieve an accuracy rate of $86.67 \%$ in predicting bankruptcy two years prior to its occurrence when it was applied to textile companies in Punjab over the period 1999 to 2010 (Gupta et al., 2013).

Shareholders, investors and creditors are most interested in financial failure probability since it influences their investment decisions and credit limits set for these companies. In turn, the financial distress score generated by the Zeta model and other bankruptcy prediction models would have an effect on their decisions which would in turn affect the share price of the company positively or negatively (Al Khatib, 2011; Al Saedi, 2016; Al Manaseer \& Al Oshaibat, 2018). Al Saedi and Al Timimi (2018) conducted a study to examine the relation between Altman's score and the share price of seven industrial companies listed at Qatar exchange market over the period 2008 to 2017. They concluded that there was a statistically significant positive relation between the share price of these companies and Altman's score indicating that investors at the Qatari stock exchange market take the scores of financial distress prediction models into consideration when evaluating the fair price of companies they invest in.

\section{Method}

The Zeta model is a model that is based on financial ratios where many researchers concluded that financial ratios are considered to be an efficient way to analyze and diagnose the financial soundness of companies (Husein \& Pambekti, 2014). The Zeta model is an augmented version of Altman's original model that was found in 1968. The Zeta model is based on five financial ratios weighted by coefficients.

$$
\text { Zeta Score }(Z)=1.2 X 1+1.4 X 2+3.3 X 3+0.6 X 4+1 X 5
$$

Where;

$\mathrm{X} 1$ = working capital (current assets $(\mathrm{CA})-$ current liabilities $(\mathrm{CL}))$ / total assets (TA)

$\mathrm{X} 2=$ retained earnings $(\mathrm{RE}) /$ total assets $(\mathrm{TA})$

$\mathrm{X} 3$ = earnings before interest and tax (EBIT) / total assets (TA)

$\mathrm{X} 4$ = equity market value (EMV) / total liabilities (TL)

X5 = Sales (S) / Total Assets (TA)

The results obtained from the model is then compared to a benchmark that is set to determine the financial soundness of the company. The criteria used to interpret the Z-score model is;

- $\quad$ Safe Zone if Zeta-score > 2.99 (risk free)

- $\quad$ Gray Zone if $1.81<$ Zeta-score $<2.99$ (at risk)

- Distress Zone if Zeta-score $<1.81$ (bankruptcy)

A regression model is then set to examine the relation between the company share price in the market as a dependent variable and the Zeta score as the independent variable as follows;

$$
S P_{i t}=\alpha+\beta\left(Z_{i t}\right)+\varepsilon_{i t}
$$

Where;

$S P_{i t}$ is the share price of company $i$ at time $t$.

$\beta$ is the coefficient of the Zeta score

$Z_{i t}$ is the Zeta score of company $i$ at time $t$.

$\varepsilon$ is the error term.

Equation 2 is set to examine the following hypothesis;

H0: There is no relation between Zeta score and the share price of healthcare companies.

\section{Results}

The results obtained from this research are based on data collected from the annual reports of the two healthcare companies over the period spanning from 2013 to 2017. The annual reports were obtained from the Kuwait Stock Market website and the database of Kuwait institute of banking studies. The amounts presented in this 
paper are presented in thousand of Kuwaiti dinars (KWD) unless mentioned otherwise.

By looking at the financials of the two companies under study as shown in table1, it can be seen that Yiaco's current assets went down from KWD 90,401 in 2016 to KWD 67,702 in 2017 which is a decrease of 25.11\% compared to an increase of $36.9 \%$ for Advanced Technology. In terms of current liabilities, Advanced Technology current liabilities increased by 55.82\% compared to a reduction of $5.81 \%$ for Yiaco. The current ratio for Advanced Technology was 1.27 times compared to 1.13 time for Yiaco in 2017, this indicates that Advanced Technology is more capable in facing short term obligations than Yiaco. In terms of leveraging, Yiaco had a leverage ratio of 8.35 times compared to 4.57 times for Advanced Technology in 2017, this would indicate that Yiaco is in risk of being unable to pay its debts when matters get worse. With the huge losses Yiaco encountered in 2017, Yiaco had a book value per share of KWD 0.047 compared to KWD 0.363 for advanced technology (the face value per share for both companies is KWD 0.100). In 2017, Advanced Technology was trading at 3.03 times its book value compared to 3.22 times for Yiaco. In determining the management efficiency for the two companies, that is the management ability to convert sales revenues into profit, Advanced technology had a ratio of $7.61 \%$ compared to $-12.67 \%$ for Yiaco which indicates the mismanagement in Yiaco.

Table 1. Companies financials (KWD '000)

\begin{tabular}{lcccccccccc}
\hline & \multicolumn{1}{c}{ Yiaco } & \multicolumn{1}{c}{$\boldsymbol{1}$} & $\mathbf{4}$ & \multicolumn{4}{c}{ Advanced Technology } \\
\hline & $\mathbf{2 0 1 3}$ & $\mathbf{2 0 1 4}$ & $\mathbf{2 0 1 5}$ & $\mathbf{2 0 1 6}$ & $\mathbf{2 0 1 7}$ & $\mathbf{2 0 1 3}$ & $\mathbf{2 0 1 4}$ & $\mathbf{2 0 1 5}$ & $\mathbf{2 0 1 6}$ & $\mathbf{2 0 1 7}$ \\
Current Assets & 76,928 & 89,035 & 93,499 & 90,401 & 67,702 & 77,980 & 89,878 & 119,708 & 151,993 & 208,078 \\
Current Liabilities & 59,254 & 66,458 & 75,573 & 63,437 & 59,753 & 54,388 & 56,971 & 78,144 & 104,930 & 163,505 \\
Networking Capital & 17,674 & 22,577 & 17,925 & 26,964 & 7,949 & 23,592 & 32,907 & 41,564 & 46,993 & 44,574 \\
Total Assets & 96,151 & 108,793 & 110,020 & 95,862 & 71,782 & 102,490 & 115,654 & 150,893 & 185,435 & 248,625 \\
Total liabilities & 61,864 & 72,413 & 80,797 & 67,281 & 63,181 & 63,001 & 73,098 & 105,693 & 136,836 & 194,232 \\
Retained Earnings & 10,149 & 10,638 & 3,587 & 3,814 & $-16,156$ & 11,857 & 13,550 & 15,704 & 18,674 & 23,707 \\
Sales & 115,282 & 107,295 & 108,583 & 90,550 & 74,645 & 67,364 & 71,294 & 96,759 & 99,112 & 168,483 \\
EBIT & 3,922 & 2,188 & $-7,005$ & 401 & $-9,588$ & 6,026 & 6,706 & 7,010 & 8,975 & 12,814 \\
Equity Market Value & 58,039 & 26,559 & 25,832 & 65,489 & 27,651 & 136,500 & 139,500 & 138,000 & 138,000 & 165,000 \\
Share Price (KWD) & 0.335 & 0.146 & 0.142 & 0.360 & 0.152 & 0.910 & 0.930 & 0.920 & 0.920 & 1.100 \\
\hline
\end{tabular}

As illustrated in table 2, Yiaco's networking capital to total assets ratio showed a decrease due to lowering in networking capital particularly in the year 2017, where the networking capital went down $70.5 \%$ between the years 2016 and 2017. The huge reduction in the retained earnings in 2017 was due to the losses the company encountered in that year. The losses also affected the EBIT to total assets ratio where it went to -0.134 for that year. The stock price of Yiaco went down in 2017 due to the company losses, these losses affected the share price of the company which went down from 360 fils ( $1 \mathrm{KWD}=1000$ fils) to 152 fils, this in turn affected the equity market value to total liabilities ratio which went down from 0.973 in 2016 to 0.438 in 2017. Despite the lower sales for Yiaco in 2017 compared to 2016 sales, the sales to total assets ratio went up from 0.945 in 2016 to 1.054 in 2017 due to the reduction in total assets which was, as a percentage, higher than the percentage change in sales.

Table 2. Financial ratios results

\begin{tabular}{lllllllllll}
\hline & \multicolumn{3}{c}{ Yiaco } & \multicolumn{5}{c}{ Advanced Technology } \\
\hline & $\mathbf{2 0 1 3}$ & $\mathbf{2 0 1 4}$ & $\mathbf{2 0 1 5}$ & $\mathbf{2 0 1 6}$ & $\mathbf{2 0 1 7}$ & $\mathbf{2 0 1 3}$ & $\mathbf{2 0 1 4}$ & $\mathbf{2 0 1 5}$ & $\mathbf{2 0 1 6}$ & $\mathbf{2 0 1 7}$ \\
X1 & 0.184 & 0.208 & 0.163 & 0.281 & 0.111 & 0.230 & 0.285 & 0.275 & 0.253 & 0.179 \\
$\mathbf{X 2}$ & 0.106 & 0.098 & 0.033 & 0.040 & -0.225 & 0.116 & 0.117 & 0.104 & 0.101 & 0.095 \\
X3 & 0.041 & 0.020 & -0.064 & 0.004 & -0.134 & 0.059 & 0.058 & 0.046 & 0.048 & 0.052 \\
X4 & 0.938 & 0.367 & 0.320 & 0.973 & 0.438 & 2.167 & 1.908 & 1.306 & 1.009 & 0.850 \\
X5 & 1.199 & 0.986 & 0.987 & 0.945 & 1.054 & 0.657 & 0.616 & 0.641 & 0.534 & 0.678 \\
\hline
\end{tabular}

In terms of Advanced Technology, as seen in table 2, the networking capital to total assets ratio went down from 0.253 in 2016 to 0.179 in 2017 due to the huge increase in total assets in that year. Despite the increase in retained earnings in 2017, the retained earnings to total assets ratio went down since the increase in total assets was more than the increase in retained earnings. The increase in EBIT in 2017 was higher than the increase in total assets which led the EBIT to total assets ratio to increase from 0.048 in 2016 to 0.052 in 2017. The increase 
in EBIT by $42.77 \%$ from 2016 to 2017 also resulted in an increase in the share price of the company which led to an increase in Advanced Technology market value. But despite the increase in equity market value, the equity market value to total liabilities went down as a result in a higher increase in total liabilities. Sales went up by 69.99\% from 2016 to 2017 which in turn resulted in an increase in sales to total assets ratio from 0.534 to 0.678 .

Yiaco has always been in the danger zone swinging between both high and gray bankruptcy risk areas as seen in table 3. Yiaco experienced the worst year in 2017 with a Zeta score of 0.693 , the lowest during the study period, which was mainly due to the huge losses encountered that year. On the other hand, Advanced Technology was in the gray area in the first three years but in the years 2016 and 2017 their financial position became worse and are facing a high risk of bankruptcy. The main reason for the deterioration in Advanced Technology's Zeta score was due to the huge increase in both total assets and total liabilities that increased by $34.07 \%$ and $41.94 \%$ respectively.

Table 3. Altman's Zeta-score

\begin{tabular}{|c|c|c|c|c|}
\hline \multicolumn{5}{|c|}{ Healthcare Companies Listed in KSE Market } \\
\hline & \multicolumn{2}{|c|}{ Yiaco } & \multicolumn{2}{|c|}{ Advanced Technology } \\
\hline 2017 & 0.693 & High & 1.706 & High \\
\hline 2016 & 1.936 & Gray & 1.744 & High \\
\hline 2015 & 1.210 & High & 2.054 & Gray \\
\hline 2014 & $1.65 \varsigma$ & High & 2.458 & Gray \\
\hline 2013 & 2.265 & Gray & 2.589 & Gray \\
\hline
\end{tabular}

Note. $2.99<$ Free, $2.99 \geq$ Gray $\geq 1.81,1.81>$ High bankruptcy risk.

When it comes to examining the relation between the Zeta score and the share price of the company, it can be seen from table 4, that the R-square of the model is 0.4421 meaning that Zeta score explains $44.21 \%$ of the variances in the stock price. The results also show that the model can be labeled as a "good fit" since the significance $F$ is lower than 0.05 indicating that the model is statistically significant at the $95 \%$ confidence level.

Table 4. Regression output

\begin{tabular}{llll}
\hline Independent Variable & Coefficient & $\boldsymbol{t}$-Stat & $\boldsymbol{p}$-value \\
\hline Zeta Score & 1.008 & 5.559 & $0.0359^{* *}$ \\
$\boldsymbol{R}$-square & 0.4421 & & \\
$\boldsymbol{F}$-statistic & 6.34 & & \\
Prob (Significance $\boldsymbol{F}$ ) & $0.0359^{* *}$ & & \\
\hline Note $* *$ 95\% confidence level. & & &
\end{tabular}

The results also show that Zeta score has a statistically significant positive relation with the stock price with a $p$-value of 0.0359 which is consistent with Al Saedi and Al Timimi (2018) findings. This means that the share price of the company increases as the Zeta score increase. The result also implies that investors at Kuwait stock exchange market do consider financial distress models, such as Zeta model, scores when considering their investment decisions.

\section{Discussion}

Healthcare companies listed at Kuwait stock exchange plays a crucial role in the healthcare industry in Kuwait. This study aimed to examine the financial soundness of these companies, using Zeta model, over the period 2013-2017 and the effect of the Zeta score on the stock price of these companies. The results obtained from this study reviled that both companies are facing the threat of bankruptcy. The results also showed that there is a statistically significant positive relation between the Zeta score and the share price these companies. This indicates that investors in the healthcare sector at Kuwait stock market pay attention to the importance of financial failure indicators which in turn affects the share price of these companies.

\section{References}

Al Gagawi, T., \& Ibrahem, B. (2015). The role of organizational structure in financial failure predicting. Management and Economics Journal, 3(9), 56-69.

Al Khatib, K. (2011). Predicting corporate bankruptcy of Jordanian listed companies: Using Altman and Kida 
Models. International Journal of Business and Management, 6(3), 208-215.

Al Manaseer, S., \& Al Oshaibat, S. (2018). Validity of Altman Z-score model to predict financial failure: Evidence from Jordan. International Journal of Economics and Finance, 10(8), 181-189. https://doi.org/10.5539/ijef.v10n8p181

Al Saedi, A. (2016). The relationship between financial failure and market value: Empirical study on the UAE industrials listed firms. Afaq Eqtsadia Journal, 37(2), 15-42.

Al Saedi, A., \& Al Timimi, S. (2018). The Relationship between Financial Failure and Market Value: An Empirical Study using a Sample of Industrial Firms listed at Qatar Stock Exchange. Academy of Accounting and Financial Studies Journal, 22(5), 1-9.

AlAli, M. (2018). Predicting Financial Distress for Mobile Telecommunication Companies Listed in Kuwait Stock Exchange Using Altman's Model. Journal of Economics, Finance and Accounting, 5(3), 242-248.

Altman, E. (1968). Financial Ratios, Discriminant Analysis and the Prediction of Corporate Bankruptcy, Journal of Finance, 23, 589-609. https://doi.org/10.1111/j.1540-6261.1968.tb00843.x

Altman, E., Haldeman, R., \& Narayanan, P. (1977). A New Model to Identify Bankruptcy Risk of Corporations. Journal of Banking and Finance, 1, 29-54. https://doi.org/10.1016/0378-4266(77)90017-6

Back, O., Oosterom, G., Sere, K., \& Van Wezel, M. (1994). A comparative study of neural networks in bankruptcy prediction. Proceedings of the 10th Conference on Artificial Intelligence Research in Finland, Finnish Artificial Intelligence Society, 140-148.

Bredart, X. (2014). Bankruptcy Model: A Case of the United States. International Journal of Economics and Finance, 6(3), 1-7. https://doi.org/10.5539/ijef.v6n3p1

Georheta, V., \& Georgeta, J. (2012). Bankruptcy prediction model for listed companies in Romania. Journal of Eastern Europe Research in Business \& Economics, 1-10. https://doi.org/10.5171/2012.381337

Gupta, S., Singh, P., \& Maheshwari, N. (2013). Employment of Zeta Model on Listed Textile Companies of Punjab. Asian Pacific Journal of Marketing \& Management Review, 2(6), 69-73.

Husein, M., \& Pambekti, G. (2014). Precision of models of Altman, Springate, Zmijewski, and Grover for predicting the financial distress. Journal of Economics, Business, and Accounting Ventura, 17(3), 405-416. https://doi.org/10.14414/jebav.v17i3.362

\section{Copyrights}

Copyright for this article is retained by the author(s), with first publication rights granted to the journal.

This is an open-access article distributed under the terms and conditions of the Creative Commons Attribution license (http://creativecommons.org/licenses/by/4.0/). 